$\underline{\text { Research Article }}$

\title{
Causal Linkages between Flood Hazards and Food Insecurity: Evidence from Nigeria
}

\author{
Felix Odemero ACHOJA ${ }^{1 *}$, O'raye Dicta OGISI ${ }^{2}$ Daniel Chukwujioke OKEKE 3
}

\begin{abstract}
This study analyzes the causal and spread effects of extreme flood on food availability and affordability, as the two dimensions of food security in Nigeria. Multi-stage sampling procedure was adopted to collect primary data from 420 farming households. Statistical methods, regression model and descriptive statistics, were used to analyze data. It was found out that household mean food security index is 0.32 $(32 \%)$ and it was significantly influenced by flood hazards in the short run. Results suggest that the flood hazards directly lead to a fall in the food availability, food consumption and welfare of vulnerable rural households. This indicates that the more the flood severity the more the food security challenge among indigenous farming households. Spillover (indirect) effects of flood hazards show the extent of spread of the hazards in the form of disease outbreak, increased dependency ratio, mass migration of flood victims, food scarcity and increase in prices of food stuffs.
\end{abstract}

Keywords: Spillover effects, flood hazards, food insecurity, vulnerable farming households

\section{Taşkın Tehlikeleri ve Gıda Güvensizliği Arasındaki Nedensel Bağlantılar: Nijerya'dan Kanitlar}

Özet

Bu çalışma, Nijerya'daki gıda güvenliğinin iki boyutu olarak, aşırı taşkınların gıdaya elverişlilik ve satın alınabilirlik üzerindeki nedensel ve yayılmış etkilerini analiz ediyor. 420 çiftçi hanesinden birincil veri toplamak için çok aşamalı örnekleme prosedürü kabul edildi. Verilerin analizinde istatistiksel yöntemler, regresyon modeli ve tanımlayıcı istatistikler kullanılmışıı. Hanehalkı ortalama gıda güvenliği endeksinin 0,32 (\% 32) olduğu ve kısa vadede taşkın tehlikelerinden önemli ölçüde etkilendiği görülmüştür. Sonuçlar, sel tehlikelerinin doğrudan gıda mevcudiyetinde, gıda tüketiminde ve hassas kırsal hanelerin refahında bir düşüşe yol açtığını göstermektedir. Bu, taşkın şiddeti arttıkça, yerli tarım haneleri arasında gıda güvenliği sorununun arttığını göstermektedir. Taşkın tehlikelerinin yayılma (dolaylı) etkileri, hastalık salgınları, artan bağımlılık oranı, taşkın kurbanlarının toplu göçü, gıda kıtlığı ve gıda maddesi fiyatlarındaki artış şeklinde tehlikelerin yayılma derecesini göstermektedir.

Anahtar Kelimeler: Yayılma etkileri, taşkın tehlikeleri, gıda güvensizliği, hassas tarım haneleri

ORCID ID (By author order)

0000-0002-9705-4923,0000-0001-6507-1940, 0000-0002-9402-0656

Recieved: 28.12 .2018

Accepted: 17.09.2019

${ }^{1 \& 2}$ Department of Agricultural Economics and Extension, Faculty of Agriculture, Delta State University, Asaba Campus, Nigeria.

${ }^{3}$ Nwafor Orizu College of Education, Nsugbe, Anambra state, Nigeria.

*E-mail: lixmero40@yahoo.com, achojafelix@gmail.com 


\section{Causal Linkages between Flood Hazards and Food Insecurity: Evidence from Nigeria}

\section{Introduction}

Flood is an unusual accumulation of water on land. A flood disaster might be caused by natural or man-made factors resulting in a significant bio-physical damage or destruction, loss of life or drastic change in the environment. Flood is capable of causing loss of properties, economic losses, social disorder and welfare loss of vulnerable people (Cherdpong et al, 2013). In Delta state and other parts of Nigeria, extreme flood event occurred in 2012. The indigenous community farmers in the flood belt are often vulnerable to floods hazards in Delta state.

In 2012, Delta State was worst hit by flood disaster resulting in food losses. It is perceived to complicate the already poor food security scenario in Nigeria. The flood destroyed food crops and livestocks in the farm. Properties worth millions of naira were destroyed. Houses and means of livelihood were destroyed as many communities were ravaged and swallowed up by the flood disaster. Refugee camps were opened at various centres in Delta State to accommodate displaced persons. People were forced to migrate from their ancestral homes. Generally, extreme flood event is capable of retarding and reversing economic development. Their vulnerability to flood hazards would aggravate their already poor welfare status. Efforts to manage flood extreme events and the associated food security challenges will require empirical information on further, food security and climate change policies requires targeting the relevant variables on the vulnerable indigenous farmers in the flood belt of Nigeria.

Today an estimated 790 million peoples suffer from nutritional deficiency. This situation is expected to be aggravated with flood hazards, especially in the low-latitude (flood belt) where the overall crops production is expected to decrease (IPCC, 2007).

Flood has close link with decrease food production yield and food availability (Meinke and Stone, 2005).
The lack of economic resources and capacity to mitigate flood hazards has necessitated a shift of research focus to the modeling of self-help community-based flood response/management approach (Msangi et al 2006; Maza, et al, 2008.

Before now, there is dearth of empirical investigation on the effect of flood hazard on food security in the flood belt of Nigeria. No study has been conducted to evaluate the capacity of indigenous people to manage flood hazards. Furthermore, there is no model so far developed to guide community-based flood management in Nigeria.

Community-based flood management models provide climate information for the benefit of community people (Ash, et al 2007; Letson et al, 2005; Roncoli, 2006. Hansen, et al. 2009). The essence of investigating flood community-based response behaviour model is therefore to involve community people participation to maintain or conserve the environment and to save their lives and properties from flood disaster through flood surveillance, and early warning/early action. The practical benefit of this study is that of policy prescription for self-help communitybased flood disaster management approaches and enhanced food security status in the advent of flood disaster in Nigeria.

Thienkamol; (2011), had earlier advocated environmental education and consciousness in relation to alleviation of extreme flood events on agriculture. Agricultural livelihood activities in Nigeria are threatened by extreme climate events such as flood which is capable of disrupting farming cycles and fishery activities in Nigeria. Effects of climate change on agriculture and related livelihood assets, including food availability of vulnerable communities could be serious (Climate Lab. Org., 2011). How serious flood hazards is to farming households especiallly with respect to food security, leaves much to be studied and therefore deserves empirical investigation.

It is important to strategically search for information on the linkages between flood 


\section{Causal Linkages between Flood Hazards and Food Insecurity: Evidence from Nigeria}

hazards and food security as well as the spillover effects on the larger society. This evidenced-based research provided information on flood frequency, flood severity and effect on food security, flood spillover effects, as well as flood and food security management strategies adopted by indiginous farmers in the flood belt of Nigeria.

Available literature suggested the possibility of relationship between flood hazards and food security. A few studies examined the effect of flood on Agricultural output (Meinke and Stone, 2005).

This study was designed to provide answers to the following questions:

i. What is the food security level of indigenous farmers during flood hazards in the flood belt of Nigeria?

ii. What are the direct effects of flood hazards on food insecurity status of indigenous households in the study area?

iii. What are the indirect or spillover effects of flood hazards in the flood belt of Nigeria?

The major objective of the study was to investigate the effect of extreme flood events on food security status in the flood belt of Nigeria. The specific objectives of the study were to:

i. determine the food security level of indigenous farmers during flood hazards in the flood belt of Delta state;

ii. examine the effect of flood hazards on food insecurity status of indigenous households in the study area; and

iii. ascertain the spillover effects of flood hazards in the flood among indigenous households belt of Delta State, Nigeria.

The null hypothesis that guided study was:

$\mathrm{HO}_{1}$ : Flood hazards do not significantly influence the food security status of farming households in the flood belt of Nigeria.

\section{Materials and Methods \\ Description of Study Area}

The flood belt of Delta state, Nigeria was the study area. This area was chosen for the study due to its vulnerability to flood hazards. This area occupies the fresh water and mangrove swamp forest along the tributaries of River Niger. The volume of water from the two biggest rivers (River Niger and River Benue) confluencing in Lokoja, kogi state and flows towards the south, down to the creeks (tributaries) in Delta state. The recurrent flood disasters in Delta state has clearly and naturally mapped out the flood belt or plains in Delta state. Delta state lies roughly between latitude $5^{0}$ and $6^{0} 30^{1}$ north. The state has more annual rainfall in the coastal areas and less in the Northern parts. The rainfall is heaviest in July with a short break in August. The state has an average ambient temperature range of about $39^{\circ} \mathrm{C}$ and $44^{\circ} \mathrm{C}$. Its natural vegetation divided into rainforest, fresh water forest and mangrove swamp forest. Hence the study area is agricultural advantageous (Achoja, 2012). The state has a total population of about 4,098,391 people (National Population Commission, 2006).

The state comprises of 25 Local Government Areas. The state is demarcated into 3 agricultural zones, namely; Delta South, delta Central and Delta North agricultural zones. The major crops grown include tree crops such as rubber, oil palm, tuber crops such as cassava, yam, coco yam; cereal such as maize and swap rice and assorted vegetables. The livestock's commonly reared include: pigs, sheep, goats, poultry and fish, both on small and large scales. The common agricultural problems of the Delta State include seasonal flooding with devastating effects on agricultural development and the welfare of the people. The map of Delta state (the study area), is shown in figure 1. 


\section{Causal Linkages between Flood Hazards and Food Insecurity: Evidence from Nigeria}

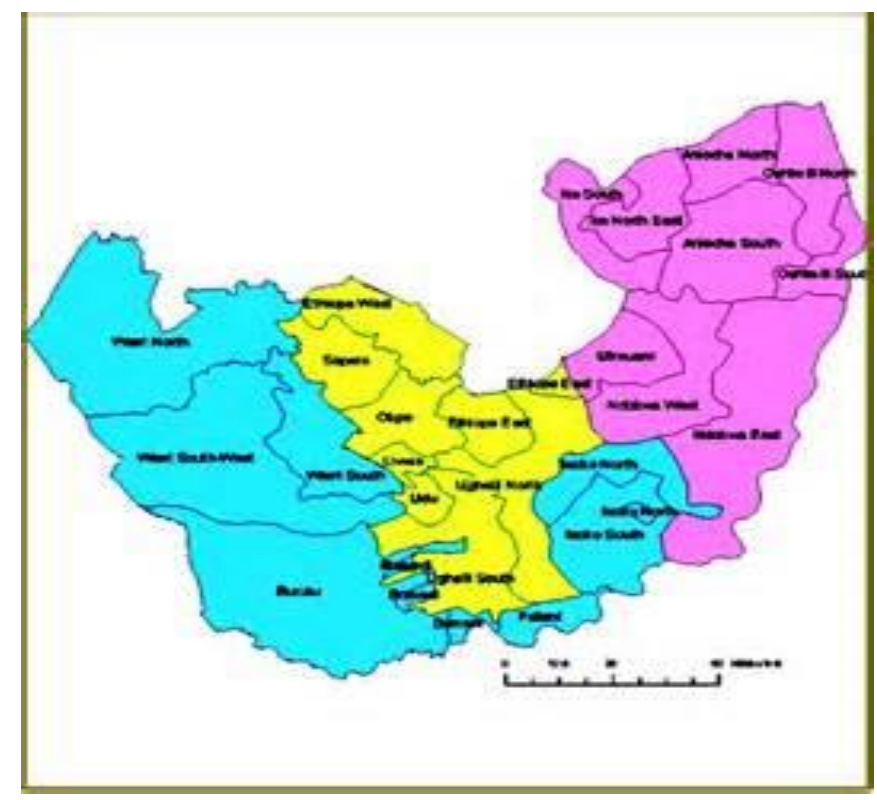

Figure 1: Map of Delta State, the Study area.

\section{Sample Size and Sampling Technique}

To avoid selectivity bias, a chance mechanism was employed to select the sample 420 respondents for the study. The sample for the study was drawn using a probabilistic procedure (multi-stage procedure). The procedure for multi-stage sampling technique that was adopted in this study is described as follows:

\section{Stage 1: Selection of Local Government Areas}

Three Local Government Areas were purposively selected from the list of Local Government Areas in the flood belt of each of the 3 agricultural zones. This gave a total of 9 Local Government Areas out of the 25 Local Government Areas in Delta State that were used for the study. They are Bomadi, Burutu, Ughelli South, Udu, Oshimili South, Ndokwa East, Warri North, Isoko North and Isoko South. The sample size accounted for $36 \%$ of the total Local Government Areas in the study.

\section{Stage 2: Selection of Farming Communities}

In each of the 9 selected Local Government Areas, 3 communities were randomly selected. This gave a total of 28 communities in the flood belt that were involved in the study.
Stage 3: Selection of Farming Households In each of the 28 selected communities, 15 farmers were selected. This gave a total sample size of 420 farming households that participated in the survey. The list of registered flood victims obtained from the Ministry of Environment formed the sample frame for the study.

\section{Data Collection Procedure}

Since the research work was based on primary data, questionnaire/interview schedule and observation were the data collection instruments used for the study. Hence preparation for field work included; questionnaire design, validation and reliability tests. Selection of key informants, recruitment and training of enumerators for 2 days. They were recruited according to certain criteria such as willingness, time devotion, commitment and knowledge of the geography and language of the study area). Enumerators were equipped with questionnaire, writing materials, phones and calculators. The enumerators were responsible for questionnaire administration and retrieval. Focus group discussion was organised and moderated by the enumerators. Similar method of primary data collection was used by (Thiengkamol, 2011). Actual field work was supervised by the lead researcher. 


\section{Causal Linkages between Flood Hazards and Food Insecurity: Evidence from Nigeria}

\section{Data Analysis Techniques}

Description statistical tools such as mean, percentage, standard deviation and frequency distribution table were used to analyze socioeconomic characteristics of respondents. Students' t-statistics was used to test the level of significant relationship between flood hazards and food insecurity status of indiginous farming households in the study area.

\section{Model Specification}

\section{Model 1}

Cost of Calorie (CoC) function proposed by Geer and Thorbecke (1986) and adopted by (Adenegan and Adewusi, 2007; \& Ojogho, 2010;) was employed in determining food security status of households. This function is estimated as:

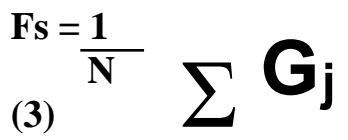

Where $G$ is expressed as: $\left(L-X_{i}\right) / L$ for the household.

Where Fs = Food security status

$$
\mathrm{L}=\text { Recommended Daily }
$$

Expenditure on Calorie (Kcal)

$\mathrm{Xi}=$ Per capita expenditure on food consumption available to households

$$
\mathrm{N}=\text { Number of households }
$$

The food security index obtained was measured on $0.0-1.0$ scale and was used to formulate the food security model.

\section{Model 2}

Response of Food Security Index to Flood Hazards

Probability of food insecurity of farming households with respect to flood disaster was analyzed using cumulative logistic probability model as specified by Pindyck and Rubinfeld (1981) and modified and used by John, et al (2013) as:

$P_{i}=F\left(Z_{i}\right)=1+$

$$
\frac{1}{1+e-\left(\alpha+\Sigma \beta_{i} X_{i}\right)}
$$

Where $\mathrm{P}_{\mathrm{i}}$ is the probability that a household is food insecured, given $X_{i}$ (the explanatory dummy variable of flood or no flood disaster) $\alpha$ and $\beta_{\mathrm{i}}$ were the parameters estimated.

\section{Results and Discussion}

The data collected for the purpose of this research was analyzed using descriptive statistics and econometric analytical techniques. Empirical evidences for the basic research questions were drawn from the results. Descriptive methods employed to ascertain the level and extent of food insecurity problems as a result of flood hazards among the different demographic and socio-economic variables in the study area while ordinary least square regression analyses showed the impact of flood hazard among sampled households.

This section reports the result of food security status of indigenous farming households during flood hazards in the study area

Food Security Status of Indigenous Farming Households in the Study Area

Table 1 shows the distribution of descriptive statistics of food security status of indigenous farming households in the flood belt of Delta state. The results show that households mean food security index is 0.32 with a standard deviation of 0.25 and coefficient of variation (CV) of $78.7 \%$ during flood hazards.

Table 1. Descriptive Statistics of Food Security Status of Indigenous Farming Households in the Study Area

\begin{tabular}{llclc}
\hline Variable & Mean & Standard deviation & No & CV \\
\hline FOOD SECURITY & $\mathbf{0 . 3 2}$ & 0.25 & 420 & $78.7 \%$
\end{tabular}

The livelihood of the household's head strongly influences the household's food security. The household vulnerability flood shocks would be influenced by the type and 


\section{Causal Linkages between Flood Hazards and Food Insecurity: Evidence from Nigeria}

amount of food made available from different sources. The sources of available food stuff forms the entry point of vulnerability to flood shocks as shown in Table 2.

Table 2 shows the distribution of the source of vulnerability of floods hazards among farming households. The result shows that crops in the field damaged by flood is the major source of vulnerability followed by livestock damaged by flood. These are the sources of income generated by farming households in the study area. Any damage cause by flood that pertains to these will increase their vulnerability to flood hazards.

Table 2. Sources of vulnerability to flood hazards among farming households

\begin{tabular}{llll}
\hline S/N & Items & Frequency & Percentage (\%) \\
\hline 1 & Livestock damaged by flood & 115 & 27.4 \\
2 & Crops in field damaged by flood & 185 & 44.0 \\
3 & Post Harvest damaged & 70 & 16.7 \\
4 & Properties loss from flood hazard & 50 & 11.9 \\
& Total & $\mathbf{4 2 0}$ & $\mathbf{1 0 0}$ \\
\hline
\end{tabular}

Effect of Flood Severity on Food Security Status of Indigenous Farming Households

A simple regression analysis was carried out to measure the impact of flood hazard on food insecurity status of households in the study area. The result showed that the linear functional form was best fitted for the regression. The $\mathrm{R}^{2}$ of $76 \%$ and F-statistics (3.17) at 5\% level of significance attest to general significance of the model. The $\mathrm{R}^{2}$ indicates that $76 \%$ of the variation in food insecurity status of households is explained by the exogenous variable flood severity in the model.

\section{Flood Severity Effect on Food Security:}

The result shows a positive and significant $(\mathrm{P}<0.05)$ functional relationship between flood severity and food insecurity (0.19). This implies that a $1 \%$ increase in severity of flood hazards would result in $0.19 \%$ impact on the food insecurity status of the households. The result suggests that the more severe a flood hazards, the worse the food insecurity of the affected households. Similar result was reported by Oluwatayo and Olutunji (2015), that consumption expenditure of respondents was negatively affected by flood hazards. It thus explains further that, the incidence of severe flooding will leave most indigenous farming households in the study area food insecured. Severe flood hazards is capable of destroying food crops in the field, post harvest/ stored food, livestocks and graze land.

The $\mathrm{R}^{2}$ square value of $76 \%$ suggests that flood severity explains $76 \%$ of the overall food insecurity status of inginoues farming households. Other factors could account for food insecurity situation of indigenous farming households in the flood belt.

Table 3. Effect of flood severity on food insecurity status of Indigenous Farming Households in the Flood Belt

\begin{tabular}{llll}
\hline Variable & Coefficients & Standard Error & t-statistics \\
\hline Intercept & 0.125 & 0.113 & 1.112 \\
Flood severity & 0.187 & 0.105 & $2.780^{* *}$ \\
\hline
\end{tabular}

$* *=$ significant at $5 \% ; \mathrm{R}^{2}=76 \% ;$ Adj. $\mathrm{R}^{2}=73 \% ;$ F-statistics $=3.17$.

Spillover effects of Flood Hazards in the Flood Belt of Delta State

Several socioeconomic activities suffer and most times are grounded to a halt after the incidence of flooding in the study area. This leaves many negative effects which magnitudes depend on the vulnerability of the livelihood activities, frequency, intensity and severity of the flood. Table 4 shows the distribution of responses on the spillover effects of flood hazards in flood belt of Nigeria. 


\section{Causal Linkages between Flood Hazards and Food Insecurity: Evidence from Nigeria}

From the responses of respondents, the study shows several dimensions of spillover effects found to be associated with post-flood events (Table 4). These include; Food scarcity and increase in price farm produce $(75 \%)$, mass migration $(72 \%)$, hunger and poverty $(62 \%)$, increase in household size and depency ratio (75\%), disease outbreak (58\%),extra governmental expenditure on evacuation and management of refugee camps $(68 \%)$, Psycho-social effects (57\%) and failed trust in the governance which may result in civil unrest $(62 \%)$.

Table 4. Distribution of Responses on the Spillover Effects Flood Hazards in the Flood belt of Delta state, Nigeria

\begin{tabular}{|c|c|c|c|}
\hline S/No & Responses & $\begin{array}{l}\text { Freq.(Yes) } \\
n=420\end{array}$ & $\begin{array}{l}\text { Percentage (Yes) } \\
\mathrm{n}=420\end{array}$ \\
\hline 1 & Flood hazard causes disease outbreak & 244 & 58 \\
\hline 2 & $\begin{array}{l}\text { Accommodating victims of flood hazards } \\
\text { will increase household size, depency } \\
\text { ratio, of households of relations thereby } \\
\text { reduce food security status }\end{array}$ & 315 & 75 \\
\hline 3 & $\begin{array}{l}\text { Social unrest due to hunger and poverty } \\
\text { effect of flood hazards }\end{array}$ & 260 & 62 \\
\hline 4 & $\begin{array}{l}\text { Flood victims suffer psycho-social trauma } \\
\text { due to loss of relations }\end{array}$ & 239 & 57 \\
\hline 5 & $\begin{array}{l}\text { Mass migration of victims of flood victims } \\
\text { from their ancestral homes to hinterlands } \\
\text { tends to complicate socio-economics } \\
\text { system }\end{array}$ & 239 & 72 \\
\hline 6 & $\begin{array}{l}\text { Flood hazards leads to food scarcity and } \\
\text { increase in prices farm produce in the } \\
\text { market }\end{array}$ & 315 & 75 \\
\hline 7 & $\begin{array}{l}\text { Extra governmental expenditure on } \\
\text { evacuation and management of refugee } \\
\text { camps of flood victims }\end{array}$ & 286 & 68 \\
\hline
\end{tabular}

Note: Multiple responses were recorded

\section{Mass Migration of Victims}

The results show that mass migration, increase in household dependency ratio and food scarcity/ increase in food prices were the more important spillover effects of flood hazards in the study area.

\section{Increase in Household Size/Dependency Ratio and Food Insecurity}

This was measured as total household size divided by the number of individuals working to support the household. The expected effect of this variable on food security is negative. The result of this study indicates that there was increase in household dependency ratio from 2:5 to 2: 12 due to the spillover effect of flood hazards in the study area. Owing to inadequacy of food resources, an increase in household size particularly, the non-working household members put heavy pressure on food consumption. As a result, available food was shared thinly to members of the family. This finding corroborates the earlier assertion of (Ojogho, 2010), who reported that an increase in the number of non-economically active members of household or dependency ratio tends to increase the food insecurity level of the households.

\section{Conclusions}

This empirical investigation covers food security levels of indigenous farmers during flood hazards. It examines the effect of flood hazards on food security status of indigenous farming households. It assesses the spill-over effect or indirect effect of flood hazards. 


\section{Causal Linkages between Flood Hazards and Food Insecurity: Evidence from Nigeria}

Food security coping strategies adopted by flood victims was examined. The result shows that rural people are highly vulnerable to flood hazards and they lack the capacity to deal with food security challenges that envelop them during flood hazards. Spillover effects of flood hazards basically includes hunger, increase in the price of food stuffs, increase in dependency ratio and mass migration of victims. The study highlights the negative relationship that exists between flood hazards and food availability among rural farming households. The study further extends the existing knowledge of flood hazards/climate change.

On the basis of the findings of this study, the following recommendations were made:

The study suggests from practical point of view that farming households in the flood belt of Nigeria should be seriously considered in the flood/disaster management program of government, non-governmental agencies and other stakeholders.

There should be buffer stock of foodstuff in the flood belt of Delta state to cushion the effect of flood hazards on food security of households. Flood and food security management requires concerted efforts of individuals, communities, government and non-governmental agencies.

\section{References}

Achoja, F.O. (2012) Financial Risk Programming, Volatility Forecasting and Management Strategies in Broiler Enterprise in Delta State, Nigeria, Ph.D Thesis Delta State University, Abraka (unpublished).

Adenegan, K.O and Adewusi, O.A(2007), Determinants of Food Security Status of Rural Households Living with HIV/AIDS in South Western Nigeria. African Journal of Biomedical Research, 10,9-18.

Ash, A.P.Mclntesh, B. Cullen, P. Carbenry and M.S. Smith, (2007) Constraints and opportunities in applying seasional climate forecast in agriculture, Australian Journal of Agriculture Resources 58,952-965.

Cherdpong, M., N. Thiengkamol and T. Thiengkamol (2013) Casual Relationship Model of Flood Response Bahaviour; Meditarranean Journal of Social Sciences 4(1) 567598. through PAIC Process; Meditarranean Journal of Social Sciences 4(1) 459-457

Climate Lab. Org (2011), Coastal development. Retrieved from http://www.climatelab.org/coastalDe velopment.

Greer, J. and Thorbeck, E. (1986). A methodology for measuring Food Poverty Applied to Kenya, Journal of Development Economics, 24: 59-74.

Hansen, W. (2002) Applying sessional climate predictions to Agricultural Production,Agricultural system 74, 305-307.

IPCC, 92007) Climate Change 2007:The Scientific Basis. Working GroupI Contribution to the Intergovernmental panel on Climate Change Fourth Assessment Report, Cambridge University Press, Cambridge.

John, M. Kuwornu, Demi M.S., Ditche field P.K.A (2014) Analysis of Food Security Status of Farming Households in the Forest Belt of the Central region of Ghana, Russian Journal of Agricultural and SocioEconomic Sciences 1(3), 26-42.

Letson, G.P. Podesta, C.D. Messiria and R.A. Ferreyra, (2005): The uncertain value of perfect ENSO phase forecast: Stochastic Agricultural price and Intra-phase Climate Variations, Climate Change,69,163-196.

Meza, F.J., J.W. Hansen and D. Osgood(2008) Economic value of sessional climate forecast for Agriculture: Review of ex-ante assessments and recommendations for future research. Journal of Applied Meteorology and Climatology.47; 1269-1286.

Minke, H and R.C. Stone, (2005), seasonal and Inter-annual Climate 


\section{Causal Linkages between Flood Hazards and Food Insecurity: Evidence from Nigeria}

Forecasting: The new tool for increasing preparedness to climate variability and change in Agricultural planning and operations Climate Change, 70,221-253.

Msangi, S.M.W. Rosegrant and L. You (2006) Ex Post Assessment Methods of Climate Forecast Impacts. Climate Research, 33,67-79.

National Population Commission,(NPC) (2006), Annual Report.

Ojogho, O.(2010) Determinants of Food insecurity among Arable Farmers in Edo State, Nigeria; Agricultural Journals 3: 151-156.

Oluwatayo1,I.B and Olutunji, K. (2015), Effect of Flooding on the Livelihood and Consumption of Households in
Oyo State, Nigeria, Journal of Economics, 6(2): 169-176.

Pindyck, S. and Rubinfeld. L. (1981), Econometric Models and Economic Forecasts, Second Edition, Second Edition, Mc Graw-Hill, New York.

Roncoli, C. (2006).Ethnographic and Participatory Approaches to research on farmers responses to climate predictions, Climate Research, 33, 81-99.

Thiengkamol, N. (2011). Development of model of Environmental Education and Inspiration of Public Consciousness Influencing to Global Warming Alleviation, European Journal of Social Science, 25(4); 506514. 